\title{
GENDER AND ELECTIONS IN BOTSWANA
}

\section{Zitha Mokomane}

\author{
Dr Zitha Mokomane is in the Department of Population Studies, \\ Faculty of Social Sciences, University of Botswana \\ P/Bag UB 0705, Gaborone, Botswana \\ Tel: +267 355 2715; Fax: +267 3185099 \\ e-mail:dewahzs@mopipi.ub.bw
}

\begin{abstract}
This paper provides a gender analysis of parliamentary elections in Botswana, with particular focus on the 2004 election. The main thrust of the argument is that although women in Botswana have made steady progress in politics and decision-making positions, socio-economic and cultural processes and structures still place men at the pinnacle of political power. The paper also discusses possible strategies that could be adopted, in addition to current measures, to further improve the prevailing situation in respect of gender power relations in the country, especially with regard to electoral politics.
\end{abstract}

\section{INTRODUCTION}

A major challenge facing governments worldwide is to develop and implement tactical and strategic mechanisms to make electoral processes acceptable to all parties and groups with respect to gender, race, class and age (Gaidzanwa 2004, $\mathrm{p}$ 1). Gender is particularly important because it is generally accepted that 'a government by men for men can't claim to be a government for people by the people' and that 'the concept of democracy will only assume true and dynamic significance when political parties and national legislation are decided upon jointly by men and women with equitable regard for the interest and aptitudes of both halves of the population' (Lowe Morna $1993 \mathrm{cf}$ Somolekae 2000, p 76). It is therefore expected that to give effect to free and fair elections a democratic political system should give all citizens - men and women - an equal opportunity to participate in elections and the electoral process as voters, candidates and electoral administrators (Kiondo 1999, p 2; Gaidzanwa 2004, p 1).

There are several reasons why an electoral environment that promotes gender equality is ideal. One argument is that the election of more women to public 
office is desirable because women are more likely than men to fight for women's rights, (Darcy et al 1987, p 15). As Gaidzanwa (2004, p 39) succinctly states:

While one cannot guarantee that women have the concerns of other women at heart, experiences in Scandinavia show that higher numbers of women representatives tend to be linked to the foregrounding of women's concerns and issues in parliament...

Another argument is based on the idea that elections are the engine of democratic governance and the primary means of political representation (Fox 1997). Therefore, Fox argues, if election dynamics change with the involvement of a new political group (such as men or women) it is of central importance to grapple with the ramifications of how this change affects the selection of top leaders. For example, Darcy et al $(1987, \mathrm{p} 17)$ argue that if the female segment of a population enters political competition with the same intensity as the male segment the quality of political leadership will necessarily improve because of the larger number of individuals involved. It is also often argued that it is only through participation in elections that the electorate influences public policy-making and implementation (Gaidzanwa 2004, p 3) and, to the extent that women have knowledge of and insights into some matters and issues that men do not, the participation of women in policy formulation is imperative if these policies are to be intelligent and effective (Darcy 1987; Fox 1997).

Against the above background, and given the centrality of elections to Botswana's political system, this paper examines elections in Botswana from a gender perspective. Particular focus is placed on the 2004 parliamentary elections (the most recent) and on three broad areas: the pre-election period, the election period and the post-election period. A brief discussion of gender equality in Botswana and the country's constitutional, legal and institutional frameworks set the stage for the rest of the paper.

\section{GENDER EQUALITY IN BOTSWANA}

Women in Botswana, like many of their African counterparts, do not enjoy equitable treatment vis-à-vis men in many substantive areas of life (United Nations [UN] 2004, p 38). However, since independence in 1966 the country has achieved much in terms of promoting gender equality. The rights of women to vote and to be elected were recognised in Botswana in the pre-independence elections in 1965 (Ntseane \& Sentsho 2005, p 190). In the political arena, progress towards gender equality has been reflected in increasing appointments of women to Cabinet and to senior positions in the civil service and in the establishment of 
a fully-fledged department (Department of Women's Affairs) within the Ministry of Labour and Home Affairs responsible for coordinating the implementation of government policy on gender. The country has also seen, in recent years, an increase in women's representation in traditional male domains such as chieftainship and the priesthood (UN 2004). Furthermore, legislation has, over the years, been reviewed and discriminatory clauses removed. It is also asserted that Botswana is one of the few countries in Africa where girls' enrolment in primary and secondary education is on a par with that of boys (Mokomane 2004).

Notwithstanding this progress, women in Botswana are still being marginalised in many aspects of life, with some of the most fundamental inequalities being their subordinate status both under the law and according to custom and their lower socio-economic status relative to that of men (Unicef 1993). For example, although the rate of unemployment is equal for males and females, there are fewer women participating in the labour force than men. Women are also largely concentrated in the low-paying sectors such as domestic service, clerical positions and other elementary occupations. Consequently, Botswana has a notable gender gap in disposable income, asset ownership and poverty (Ministry of Health 1997, p 7). The country also has a high proportion of female-headed households ( $46 \%$ at the time of the 2001 census). By their nature, these households tend to be poorer than their male counterparts due, inter alia, to low resources bases (which result from women's low wage-labour participation), high dependency ratios and the relative shortage of wage earners (Lesetedi, 2003).

\section{CONSTITUTIONAL, LEGAL AND INSTITUTIONAL FRAMEWORK}

With particular focus on the electoral process, this section sets out the constitutional, legal and institutional frameworks that prevail in Botswana and briefly evaluates their ability to facilitate women's participation in elections.

\section{Constitutional and Legal Framework}

Section 3 of the Botswana Constitution states, in part:

... every person in Botswana is entitled to the fundamental rights and freedoms of the individual, that is to say, the right, whatever his race, place of origin, political opinions, colour, creed or sex ...

Therefore, to the extent that it guarantees equality and individual freedoms and human rights, the Constitution does not discriminate against women and it places 
no restriction on their participation in politics. Nonetheless, women's presence in the political structure at both local and national levels remains insignificant because of cultural and structural barriers. These include women's socialisation right from childhood when they are directed away from activities of power, thus rendering them less ambitious than men (Somolekae 2000, p 77). Other barriers include a lack of financial and other resources, lack of political skills, will and ambition, sexual division of labour and male domination of political parties and patriarchy (Somolekae 2000; Ntseane \& Sentsho 2005).

The Constitution of Botswana provides for a Westminster-type unicameral legislature whose members are elected through a constituency-based first-pastthe post (FPTP) or simple majority electoral system every five years (Molomo 2005; Osei-Hwedie \& Sebudubudu 2006). This system, which allows the candidate who attains a simple majority in a ward or constituency to win the seat, has been criticised as benefiting men over women. For example, Gaidzanwa (2004) has noted that in Zimbabwe, where political party membership is a prerequisite for election to Parliament, the system tends to rule out the participation of a large number of women, especially those of child-bearing and rearing ages. This, according to Gaidzanwa, is largely because active party membership requires time, energy, resources and skills that many African women, including those in Botswana, cannot adequately meet because of their relatively lower economic status and often limiting social and reproductive roles.

\section{National, International and Regional Instruments}

Elections in Botswana take place against a backdrop of several national documents the government has developed over the years to promote equal rights for men and women at all socio-economic and political levels. These documents include the National Policy on Women and Development, the adoption of which marked a major milestone in recognising the important role of men and women in decisionmaking; the National Gender Programme, which prioritised power-sharing between women and men as one of the six critical areas of concern for Botswana; and Vision 2016, which commits government and other stakeholders to ensuring that positive measures are taken to enable women to participate fully in positions of power, leadership and decision-making at all levels of the society by the year 2016 (Ntseane \& Sentsho 2005, p 194).

The Botswana government has also ratified a number of international and regional treaties to, inter alia, promote and protect women's participation in decision-making processes. Key among these are the Convention on the Elimination of all Forms of Discrimination Against Women (CEDAW), the African Charter on Human and People's Rights of Women in Africa (ACHPR), The Nairobi 
Forward Looking Strategy, the Beijing Platform of Action, the Commonwealth Plan of Action on Gender and Development, and the Southern African Development Community (SADC) Declaration on Gender and Development. The specific components of these treaties are beyond the scope of this paper save to state that they unequivocally commit governments to integrating gender perspectives in legislation, public policies, programmes and projects, particularly ensuring equal access for women to, and full participation in, power structures and decision-making (Ntseane \& Sentsho 2005, p 193). The SADC Declaration went a step further, asking SADC heads of state explicitly to commit themselves to the achievement of at least 30 per cent of women in the political and decisionmaking structures by the year 2005 (SADC 1999, p 21).

While more still needs to be done to further improve gender equality in Botswana it can be concluded that these documents have played, and continue to play, a key role in creating an enabling environment for the promotion of gender equality in the country's politics and electoral processes.

\section{Administrative Framework}

The Independent Electoral Commission (IEC) is responsible for arranging and conducting the election of members of Parliament and local government as well as for conducting referenda. The commission was established by s $65 \mathrm{~A}$ of the Constitution of Botswana in 1997 (Constitution Amendment Act No18 of 1997) and consists of seven members - a chairperson, deputy chairperson, and five other members - appointed by the Judicial Service Commission on the recommendation of the All Party Conference. Currently, none of the members is a woman. While such a gender bias might not affect the management of elections per se, it may play a major role in perpetuating the sidelining of women's concerns. As stated above evidence from Scandinavian countries has shown that higher numbers of women representatives tend to be linked to the foregrounding of women's concerns and issues, whereas the continued marginalisation of women in decision-making bodies usually perpetuates the sidelining of such concerns (Gaidzanwa 2004, p 39).

\section{A GENDERED ANALYSIS OF ELECTIONS IN BOTSWANA}

Although the rights of women to vote and to be elected has been recognised in Botswana for four decades and the country continues to create an environment that promotes gender equality in participation in the electoral process, a review of some of the different ways of analysing the gender dimensions of issues in an election (Gouws 1999) reveals the existence of a gender gap. The following sub- 
sections illustrate this by analysing various components of the 2004 parliamentary elections.

\section{The Pre-Election Phase}

After the 1999 general election a number of developments took place which had a direct effect on the 2004 elections. These included the 2001 national Population and Housing Census, which showed an increase in population, and the decision by Parliament to increase the number of popularly elected members of the National Assembly from 40 to 57 and the total number of popularly elected councillors from 406 to 490 . Consequently, as required by the Constitution, the Judicial Service Commission appointed a Delimitation Commission in 2002 to draw boundaries for the newly enlarged constituencies. This exercise, conducted by demarcation committees delegated by the IEC Secretary, took place between March and July 2003. The committees demarcated the 490 polling districts and established 2178 polling stations, facilitating the declaration of the voter registration period (Independent Electoral Commission 2005, p 1).

\section{Voter registration}

A general voter registration for the 2004 election was carried out in all 57 constituencies in November 2003. At the end of the registration period 63,1 per cent of the target figure of 675000 voters had registered. Although the IEC viewed this figure as 'satisfactory', three more continuous registration exercises were carried out in the period between December 2003 and July 2004.

Analysis of various registration data in the country suggests that women tend to be more enthusiastic about the process than men. For example, in May 2004 (five months before the election) an opinion poll conducted by the University of Botswana Democracy Research Project (DRP) showed that 73,8 per cent of women had registered compared with 69,2 per cent of men. Of those who had not registered, more men $(53 \%)$ than women $(48,1 \%)$ reported that they intended to register before the election. However, post-election figures from the IEC indicate that of the 552849 eligible voters who eventually registered 311508 (56,3\%) were women and 47,3 per cent men.

\section{Nominations}

Leaders of four political parties: the Botswana Congress Party (BCP), the Botswana Democratic Party (BDP), the Botswana National Front (BNF) and the New Democratic Front (NDF) - all of them men - were nominated as candidates for election to the office of President in 2004 (IEC 2005, p 8). 
Parliamentary and local government nominations were held in terms of the Electoral Act in all 57 constituencies and 490 polling districts. Table 1 shows the number of nominated parliamentary candidates by gender and political party.

The table shows that only three of the seven parties that contested the election fielded women parliamentary candidates; the two independent candidates were also men. Of those parties which fielded women, the ruling BDP, which had the largest number of candidates and which covered all 57 constituencies, had the highest number of women parliamentary aspirants. It was followed by the BNF and the $\mathrm{BCP}$, in that order.

Overall, however, women constituted a small proportion $(7,3 \%)$ of the total number of parliamentary candidates. As Meena (1997) observed about Tanzania, this scenario affects, to some extent, women's participation in decision-making in the public spheres. For example, when making ministerial appointments the President, who, by law, has to make his choice from members of the National Assembly, has a limited pool of women to choose from.

Table 1

Gender Representation of Parliamentary Candidates in Botswana's 2004 General Election

\begin{tabular}{|l|c|c|c|c|}
\hline Party & $\begin{array}{c}\text { No of seats } \\
\text { contested }\end{array}$ & Males & Females & $\%$ Female \\
\hline Botswana Alliance Movement & 7 & 7 & 0 & 0.0 \\
\hline Botswana Congress Party & 50 & 48 & 2 & 4.2 \\
\hline Botswana Democratic Party & 57 & 50 & 7 & 14.0 \\
\hline Botswana National Front & 42 & 38 & 4 & 10.5 \\
\hline Botswana People's Party & 5 & 5 & 0 & 0.0 \\
\hline MELS Movement of Botswana & 4 & 4 & 0 & 0.0 \\
\hline New Democratic Front & 11 & 11 & 0 & 0.0 \\
\hline Independents & 2 & 2 & 0 & 0.0 \\
\hline Total & $\mathbf{1 7 8}$ & $\mathbf{1 6 5}$ & $\mathbf{1 3}$ & $7.3^{*}$ \\
\hline
\end{tabular}

* This figure is derived by dividing the total number of females who contested seats (13) by the total number of parliamentary seats (178)

Source: IEC 2005. 


\section{Campaigns}

Election campaigns give candidates an opportunity to present themselves to the electorate and to sell their party policies and ideologies to their constituencies (Meena 1997; Kiondo 1999). In multiparty democracies these campaigns can be very expensive as they require resources such as offices, staff, reliable vehicles and funds for advertising (Meena 1997; Molomo \& Sebudubudu 2005, p 148). In Botswana the situation is aggravated by the absence of any substantial state political funding, which has resulted in the majority of political parties being under-resourced and dependent, to a large extent, on volunteers and candidates' personal resources to run campaigns. As Ntseane \& Sentsho (2005, p 201) have stated, 'the road of council and parliament is determined largely by availability of adequate personal income'. While both men and women in Botswana experience difficulties in raising sufficient funds for their campaigns, the problem is greater for women, given their relatively lower socio-economic status.

Largely because of their social and reproductive roles, women candidates running campaigns and shouldering domestic responsibilities are also overworked and likely to burn out. Women's participation in the electoral process is further limited by late-night meetings and by frequent (and often long-distance) travelling to meetings, rallies and other related activities that typically characterise election campaigns (Gaidzanwa 2004, p 19). Women also face more challenges than men during campaigns because of their limited experience and political networks as well as their socialisation. For example, in addition to official campaigns, candidates often carry out informal campaigns. Although the impact of these campaigns on election results is still limited, there is evidence in different countries that they do influence the electoral process (Meena 1997, p 238). Men tend to use entertainment and public places such as bars to carry out informal campaigns and to strategise, while women's traditional and socially constricted moral conduct limits their active participation in informal campaigns that take place at 'socially unacceptable' times and in places such as bars (Meena 1997; Kiondo 1999).

As a result, women in Botswana, as in many other African countries, enter the campaign ground from a disadvantaged position, and this may partly explain why they constituted only a small proportion of parliamentary candidates in the 2004 general election (Table 1) and an even smaller proportion of those who won, as will be shown below.

\section{Party manifestos}

Closely related to election campaigns are party manifestos, a review of which is one of the most common ways of analysing the gender dimension of issues in an election (Gouws 1999, p 163; Letuka et al 2004). For the purpose of this paper, 
party manifestos used in the 2004 general election by four parties - the BCP, the $\mathrm{BDP}$, the BNF and the NDF - were reviewed. The review revealed that all the parties made commitments to empower women in the event of their being voted into power. While the BDP succinctly summarised this commitment in a short paragraph, the other parties had explicit chapters / sections devoted to women's empowerment/gender equality. While this is impressive, it can also be said that the commitments were generally full of rhetoric in that they tended to treat gender equality as a separate socio-economic issue and they lacked any evidence of a plan to mainstream it into other spheres. For example, although there is ample evidence that the HIV / AIDS pandemic affects more women than men, the manifestos' plan to address HIV/AIDS did not include any explicit statements about concrete actions to be taken by the parties to deal with the situation.

\section{Voting intentions}

Voting intentions are usually a good indicator of the way people will vote on election day (Gouws 1999, p 161). The DRP May 2004 Opinion Poll therefore asked a number of questions about voting intentions. The results show that 91,2 per cent of women, compared with 88,9 per cent of men, intended to vote. In response to the question 'if elections were held today, which political party would you vote for?' the majority of women $(51,9 \%)$ named the BDP, followed by 17,7 per cent who chose the BNF, and 11,6 per cent who refused to say which party they would vote for. The results for men followed the same pattern: $\operatorname{BDP}(40,9 \%)$, $\operatorname{BNF}(24,2 \%)$ and 14,2 per cent who refused to say. The gender gap in the intention to vote for all the other parties was negligible and more or less equal (see Figure 1).

Figure 1

Voting Intentions by Political Party and Gender, Botswana 2004

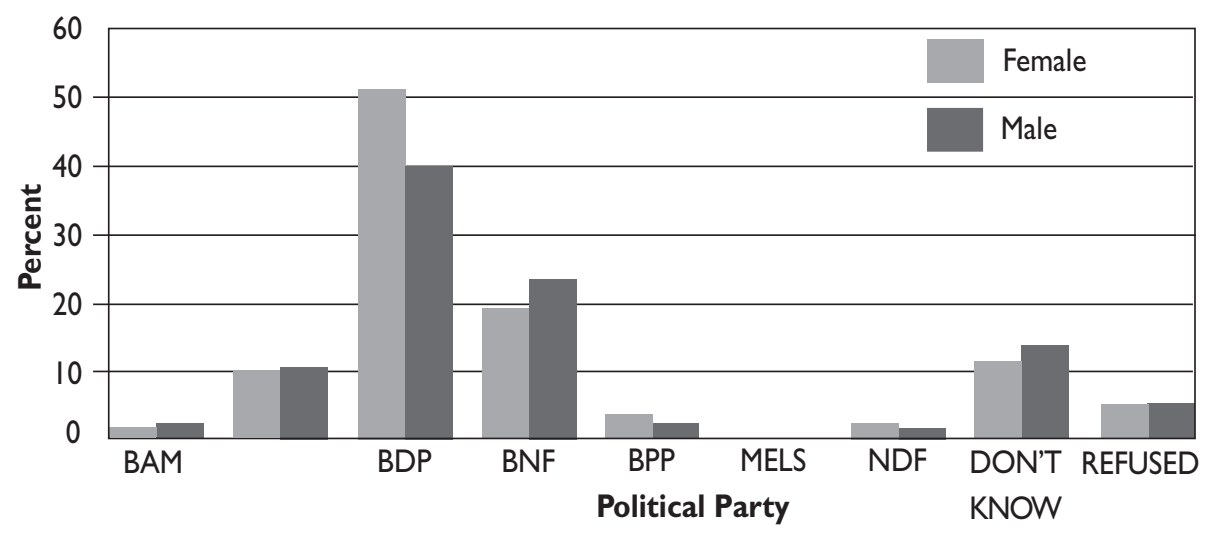

Source: Democracy Research Project 2004 Opinion Poll Data 
Overall, the results indicated that men are more likely than women to state that they intend to vote for the opposition. These results are consistent with those found by Mokomane (2000). Drawing from the literature Mokomane argues that this might be a reflection of the fact that women are usually more conservative than men and more likely to support the major party of the right. The results may also indicate that mobilised voting, where women follow the political behaviour of their male relatives, is decreasing and is being replaced by a new breed of women whose political actions are independent of those of their male relatives (Mokomane 2000).

\section{Attitudinal data}

Attitudinal data on various issues may also be used to determine whether a gender gap really exists in an election (Gouws 1999, p 165). Results of the DRP Opinion Poll show that there was no clear difference of opinion between men and women with regard to the most pressing problems facing the country: the majority of both (41,4\% and $44,2 \%$ respectively) saw unemployment as the most pressing issue; HIV / AIDS was mentioned by 13,4 per cent of women and 10,7 per cent of men and education by 6,4 per cent of women and 5,3 per cent of men. All other issues were mentioned by less than 5 per cent of both men and women, implying that they were not seen as major problems.

However, when it came to issues specifically concerning women, there was a definite difference of opinion between women and men. For example, while 85,2 per cent of women shared the view that women are capable of holding any office in the country, only 69,1 per cent of men held that view. In the same vein, 70 per cent of women and 52 per cent of men believed that a woman would be able to hold the office of president.

The results also revealed that while more than three-quarters of both women and men said they would vote for a woman candidate in their constituency, the proportion was higher for women $(88,3 \%)$ than for men $(76,6 \%)$. By the same token, when asked if political parties should develop a quota system to ensure more women's representation in Parliament, more women $(65,7 \%)$ than men $(52,5 \%)$ agreed.

Implicit in these results is a general lack of appreciation of the capacity of women to run for political office and, in particular, men's lack of confidence in women as public office bearers. This is despite the efforts by civil society organisations such as Emang Basadi and the Botswana Caucus for Women in Politics to educate and sensitise the general public about the role of women in politics (Ntseane \& Sentsho 2005, p 201). The factors underlying this situation are worthy of study. 


\section{THE ELECTION PHASE}

Voting is the ultimate activity in the election process as it is the physical expression of the electorate's exercise of its right to determine its leaders for the following five years (Lekuta 2004, p 57). Polling for the 2004 general election took place on 16 October for Botswana citizens residing in selected countries outside Botswana and on Saturday 30 October for those residing in Botswana. Overall, 76,2 per cent of the 552849 registered voters cast their ballots. Figure 2 shows the number of people who voted by gender and age group. The IEC is still in the process of compiling data for women aged 26-35, hence it is missing from the graph. Nonetheless, it can reasonably be concluded from results of the other age groups that in general more women than men voted. This finding is consistent with those of past elections in Botswana (DRP 2002).

Figure 2

Number of People Who Voted in the 2004 Botswana General Elections by Gender and Age Group

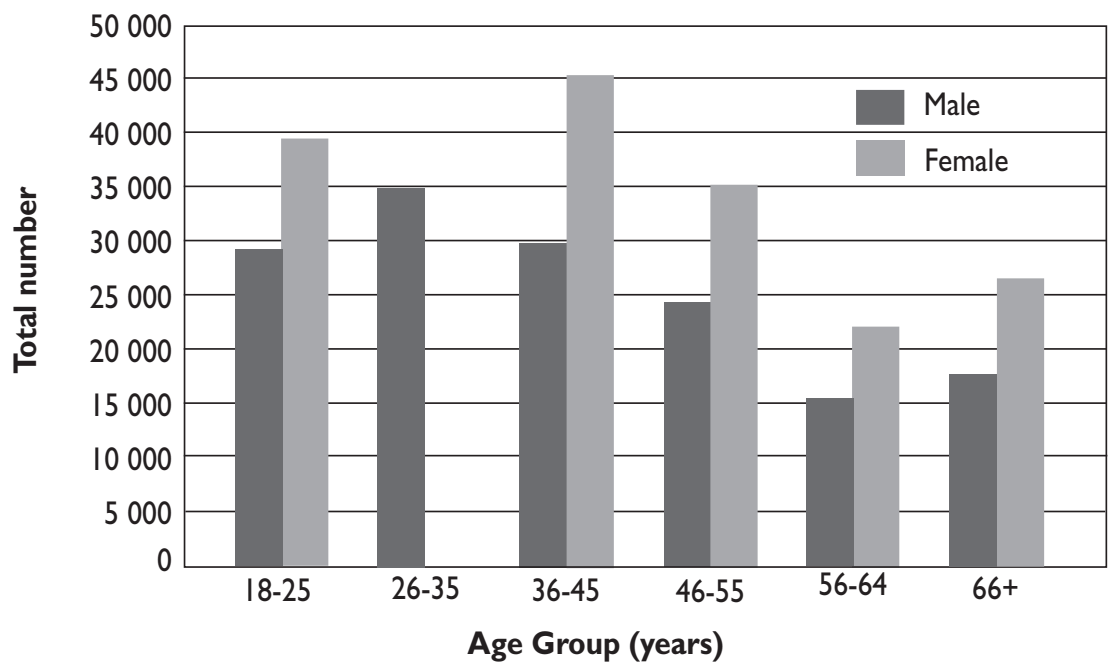

THE POST-ELECTION PHASE

Results

The first issue in analysing election results is the distribution of seats by gender (Gaidzanwa 2004, p 44). In the 2004 election the BDP won 44 of the 57 parliamentary seats $(77 \%)$ while the opposition won the remaining $13(23 \%)$. Four women, all from the BDP, won parliamentary seats. While this figure represents 
31 per cent of the total number of women who stood, it is only 7 per cent of the overall number of seats contested. This not only shows a reversal of the encouraging trend that started with the 1984 elections where, albeit still low, the number of women elected to Parliament was steadily increasing, it also indicates Botswana's dismal failure to reach the minimum SADC requirement of 30 per cent women's representation in Parliament in 2005. The results also place Botswana below relatively new democracies in the SADC region such as Mozambique, Namibia and South Africa (Ntseane \& Sentsho 2005). Given that more women than men voted the results also indicate that men are voted into power by women, while women are excluded by other women.

\section{Formation of Parliament}

The National Assembly is the lower chamber of Botswana's bicameral Parliament. The current National Assembly, formed after the 2004 general election, has a total of 63 members. Fifty-seven of them were directly elected in the parliamentary elections for a term of five years, four were specially elected (co-opted) and the remaining two (the president and the attorney general) are ex-officio. Three of the four specially elected members were women. While the co-option of members increased the de facto number of women members to seven $(11,5 \%)$, this proportion still falls short of the SADC requirement.

It is also noteworthy that one of the women members elected was subsequently elected deputy speaker of the National Assembly, a position she still holds.

\section{The Cabinet}

The president selects the Cabinet from the members of the National Assembly. It consists of a vice-president and a flexible number of ministers and assistant ministers, currently 15 and 6, respectively. The current five female ministers constitute 18,2 per cent of the 22-member Cabinet.

\section{CONCLUSION AND RECOMMENDATIONS}

Results of the 2001 population and housing census showed that women constitute more than half of the overall citizen population and of the population eligible to vote (that is, citizens aged 18 years and above). Given these proportions, Batswana women's voting behaviour will have an important impact on election results. This paper shows that while the government of Botswana can generally be applauded for providing an enabling environment for democratic elections, a 
complex web of socio-economic, cultural and structural processes embedded in the general society continues to hamper women's full participation in the electoral system. Consequently, men still largely control political power in Botswana.

Therefore, to further enhance women's participation in politics and in decision-making positions in the public domain there is a need to define mechanisms to support women who aspire to political office during all stages of elections. To achieve this, students of women in politics (eg, Meena 1997 and Shayo 2005) have shown that specific attention should be paid to the following issues:

- Gender mainstreaming in political party processes and procedures used for nominating candidates for both parliamentary and presidential positions.

- Defining and promoting mechanisms to address problems faced by women during election campaigns.

- Conducting in-depth research to identify, understand and address structural gender inequalities in society and within the electoral system.

- Analysis of election results from a gender perspective.

- Establishment of gender-sensitive monitoring and evaluation tools for advocacy purposes.

\section{- REFERENCES —}

Darcy, R, S Welch \& J Clark. 1987. Women, Elections \& Representation. Lincoln, Nebraska: University of Nebraska Press.

Democracy Research Project. 2002. Voter Apathy Report. Gaborone: The Independent Electoral Commission.

Fox, R L. 1997. Gender Dynamics in Congressional Elections. London: SAGE Publications.

Gaidzanwa, R. 2004. Gender, Women and Electoral Politics in Zimbabwe. EISA Research Report No 8.

Gouws, A. 1999. 'A Gender Dimension of the 1999 Election'. In A Reynolds (ed). Election '99 South Africa: From Mandela to Mbeki. Oxford: James Currey. Independent Electoral Commission. 2005. Report to the Minister of Presidential Affairs and Public Administration on the 2004 General Elections. Gaborone: Independent Electoral Commission.

Kiondo, E. 1999. Elections, Electoral Processes and Women's Empowerment in the Coming Millennium. Paper presented at the 4th Annual Gender Studies Conference, Dar es Salaam, 27-30 September 1999. 
Lesetedi, G N. 2003. 'Household Perspectives of Women and Men in Botswana'. In Analytical Report: 2001 Population and Housing Census. Gaborone: Central Statistics Office.

Letuka, P, M Mapetla \& K Matashane-Marite. 2004. Gender and Elections in Lesotho: Perspectives on the 2002 Elections. EISA Research Report No 4.

Meena, R. 1997. 'Gender Issues in the 1995 General Elections in Tanzania'. In S S Mushia \& R S Mukandala (eds). Multiparty Democracy in Transition: Tanzania's 1995 General Elections. Dar es Salaam: Tanzania Election Monitoring Committee.

Mokomane, Z S. 2000. 'Demographic Factors and Party Preference in Botswana: A 1999 Voter's Survey'. PULA: Botswana Journal of African Studies 14(1).

- 2004. No Rings Attached: An Exploration of the Levels, Correlates and Sociodemographic Implications of Cohabitation in Botswana. Unpublished Doctoral Thesis, The Australian National University.

Molomo, M. 2005. 'Electoral Systems and Democracy in Botswana'. In Z Maundeni (ed). 40 Years of Democracy in Botswana: 1965-2005. Gaborone: Mmegi Publishing House.

\& D Sebudubudu. 2005. 'Funding of Political Parties in Botswana: Leveling the Political Playing Field'. In Z Maundeni (ed). 40 Years of Democracy in Botswana: 1965-2005. Gaborone: Mmegi Publishing House.

Ministry of Health. 1997. Botswana HIV and AIDS: Second Medium Term Plan. Gaborone: Ministry of Health.

Ntseane, D. 2005. 'Women in Party Politics'. In Z Maundeni (ed). 40 Years of Democracy in Botswana: 1965-2005. Gaborone: Mmegi Publishing House.

\& J Sentsho. 2005. 'Women's Representation in Parliament and Council: A Comparative Analysis'. In Z Maundeni (ed). 40 Years of Democracy in Botswana: 1965-2005. Gaborone: Mmegi Publishing House.

Osei-Hwedie, B and D Sebudubudu. 2005. 'Botswana's 2004 Elections: Free and Fair?' Journal of African Elections 4(1).

SADC. 1999. Women in Politics and Decision-making in SADC: Beyond 30 per cent in 2005. Report of the proceedings of a conference held in Gaborone 28 March-1 April. Gaborone: Printing and Publishing.

Shayo, R. 2005. Women Participation in Party Politics During the Multiparty Era in Africa: The Case of Tanzania. EISA Occasional Paper Number 34, July 2005.

Somolekae, G. 2000. 'Widening the Frontiers of Democracy: Towards a Transformative Agenda in Botswana Politics'. PULA: Botswana Journal of African Studies 14(1).

UNICEF. 1993. Children and Women in Botswana: A Situation Analysis. Gaborone: UNICEF.

United Nations. 2004. Botswana Millennium Development Goals Status Report 2004: Achievements, Future Challenges and Choices. Gaborone: United Nations. 